\title{
Master of Public
}

MPG Governance

\section{Har en leder altid}

ansvaret, og aldrig

skylden?

- Om lederes læring ved undervisning

i ansvar i ledelse

\section{ANSVAR • SKYLD • DET PERSONLIGE LEDERSKAB \\ LEDERUDDANNELSE}




\section{Har en leder altid ansvaret, og aldrig skylden? \\ - Om lederes læring ved undervisning i ansvar i ledelse}

\section{ANSVAR • SKYLD • DET PERSONLIGE LEDERSKAB LEDERUDDANNELSE}

En reform, der skulle føre til bedre uddannelse for borgerne, faldt til jorden, og medarbejderne fik stress. En beboer på en døgninstitution gik ud for at stemme, og kom aldrig hjem igen. Begge disse to eksempler handler om ledelsesbeslutninger, hvor noget går galt. $\mathrm{Og}$ sådan er det med mange eksempler i ledelse: Tingene går ikke altid som forventet, og så leder omgivelserne efter, hvem der har ansvaret. Hvem har skylden. Denne artikel beskriver en undersøgelse af, hvordan det personlige lederskab er både en fordel og en hæmsko for lederskabet i forhold til ansvar og skyld. Det er en fordel at tale om et personligt lederskab, fordi det sætter lederens valg på spidsen, når det drejer sig om ansvar. Det er en hæmsko, at tale om det personlige lederskab, når det drejer sig om skyld, netop fordi det sætter lederens person på spil på en tvetydig måde. Er lederen "skyldig", når ting går galt, og hvordan har denne bagside af ansvar ("skyld") noget med lederens person at gøre? Disse spørgsmål diskuteres igennem en undersøgelse af, om og hvordan undervisning i ledelse, ansvar og skyld påvirker lederes opfattelse af disse emner. Konklusionen er, at det personlige lederskab netop skal forholde sig til spørgsmål om det etiske i det politiske for at holde fokus på opgaven, og hvordan ledere kan forholde sig til begivenheder i et politisk rum, også når det går galt. 


\section{Camilla Sløk}

Cand.theol. fra Københavns Universitet, 1996. Master (Th.M) fra Princeton Theological Seminary, Princeton, 1997. Ph.d. fra Københavns Universitet, 2003. Ansat på CBS i 2004. Stifter af Center for Skoleledelse. Idéudvikler af valgfaget "Eksistens og ledelse" på MPA og MPG siden 2007. Tidligere stillinger: sognepræst i Domkirken i København og på Rigshospitalet. Seminarielærer på Blaagaard Seminarium. Modtager af Københavns Universitets guldmedalje for speciale om Niklas Luhmann, 1996. Modtager af FSEBs pris for forskningsformidling 2018. 


\section{Ansvar og skyld i ledelse}

Den gode leder vil gerne tage ansvaret, men når tingene går galt, vil ingen tage skylden. Hvordan hænger det sammen? Denne artikel beskriver en undersøgelse af, hvordan det personlige lederskab er både en fordel og en hæmsko for lederskabet $\mathrm{i}$ forhold til ansvar og skyld. Det er en fordel at tale om et personligt lederskab, fordi det sætter lederens valg på spidsen, når det drejer sig om ansvar. Det er en hæmsko, at tale om det personlige lederskab, når det drejer sig om skyld, netop fordi det sætter lederens person på spil på en tvetydig måde. At tale om det personlige lederskab er således en mere ambivalent størrelse, når det det drejer sig om problemer eller bagsiden af ansvaret, nemlig skylden, kritikken og balladen. Her bliver det personlige lederskab pludselig ikke længere personligt - derimod bliver "skyld" noget, der hører til rollen. Hvis det overhovedet hører til nogle steder. Mange af tidens skandaler peger på denne ansvars-, og skyldfralæggelse fra nogle lederes side. Men hvordan er det gået til? Historisk har man ikke altid opfattet lederskabet som personligt, som jeg vil vise i det følgende.

\section{Historisk vue over teorier om ansvar i ledelse}

I det følgende vil jeg kort fremstille tre forskellige opfattelser af ansvar i forhold til ledelse. De stammer fra Max Weber (1864-1920), Chester Barnard (1886-1961) og Bernard Bass (1925-2007). De tre mænds opfattelse af ledelse viser spændet i tænkningen omkring ansvar i ledelse både op igennem det 20. århundrede, men også i dag.

For Max Weber var ansvar i ledelse bundet op på embedsmanden og på bureaukratiet (Weber, 1971; se også du Gay, 2007). Det var igennem adskillelsen af personen og embedet, at autoriteten fremstod, og fik legitimitet igennem rationalitet. Weber skrev også om en anden form for lederskab, nemlig karismatisk lederskab, som alene er bundet op på individers personlige evner (om man er karismatisk eller ej), men for Weber var denne organisationsmåde omkring en karismatisk ledelse ikke at foretrække.

Dette ser vi ændre sig en smule med den efterfølgende organisationstænker Chester Barnard, og helt radikalt anderledes og positivt ser Bernard Bass på den karismatiske leder. Faktisk ønsker Bass kun karismatiske ledere (Bass, 1985). Dette ville have undret Weber, som ville have foretrukket den objektive, nøgterne og rationelle leder, der træffer sine beslutninger i kraft af tydelighed og hierarkiets styrke. Hierarkier viser jo nemlig også, at der står viden og autoritet bag. Det gør der ikke nødvendigvis, når den karismatiske leder farer hen over sletten.

Den berømte organisationsforsker, Chester Barnard står et sted midt imellem Weber og Bass. Barnard udgav i 1938 en bog om lederens roller, som fik skelsættende betydning for den efterfølgende organisationsforskning. I bogen The Functions of the Executive (Barnard, 1968) beskriver han ledelsesautoritet som bestående af 1) positionens autoritet, og 2) leadership autoritet. Det første handler om, at man som leder har magt alene i kraft af rollen. Det andet handler om at have magt til at få folk til at følge sig. Denne anden del handler altså i højere grad om, at nogle personligheder får folk til at følge sig. Det er ikke altid, at de to ting følges ad: Det kan være en anden person(lighed) end lederen i organisationen, som får folk til at følge sig. Hvis de to 
imidlertid falder sammen, altså at lederen både har positionen og personligheden, vil folk følge denne leder uden at kny, eller som Barnard kalder det "uden for zonen for indifference". Medarbejderen vil engagere sig og ikke bare parere ordre.

Dette sidste, at medarbejderen skal engageres af lederen, er Bernard Bass helt enig i. Og kun det. Ledelse handler om følgeskab og ikke om position, selvom folk i ledelsespositioner selvsagt vil gøre alt for at få evnen til at få folk til at følge sig. I Bernard Bass' bog Leadership Beyond Expectation (1985) er Bass alene optaget af den anden del, nemlig følgeskabet og altså den leder, der kan skabe transformationer $\mathrm{i}$ organisationen.

Det interessante ved dette spænd fra 1918, 1938 til 1985 er, at det også viser et enormt spænd i diskussionen af ansvar. For Weber (1971) er ansvar det overordnede emne: Det er derfor, vi har organisationer, og helst bureaukratiet, som gør beslutninger tydelige. For Barnard (1968) er det også helt klart, at ansvaret ligger i ledelsens position, også selvom han benævner uformel ledelse, altså personlighed som et ledende element. Men hos Bass bliver begrebet om "ansvar" helt væk, idet han er mest optaget af lederens ansvar for at få folk til at følge sig. Og det er der, ledelseslitteraturen er i dag: Det vigtigste for en leder er at kunne få folk med. Men inden for hvilke rammer, folk skal følge med eller ikke følge med er mere uklart end hos Weber og Barnard. Det skyldes, at Bass hverken beskæftiger sig med organisationsteori eller med etik, men med følgeskab. Han er dog også selv klar over, at der kan skabes følgeskab omkring mange ting: Også Hitler og Idi Amin havde følgere, som han selv skriver. Han kommer imidlertid aldrig nærmere ind på, hvordan man skiller skidt fra kanel.

\section{Forskning i ansvar og skyld i ledelse}

Siden 2007 har jeg undervist flere hundrede studerende på Master in Public Governance (MPG) uddannelsen i etik og dilemmaer i ledelse i valgfaget "Eksistens og ledelse". Jeg skabte selv faget for 11 år siden og har undervist i det på to lederuddannelser (MPA og MPG) i 11 år. Igennem årene har faget ført til mange krævende og givende samtaler om etiske spørgsmål, som dukker op vedr. ansvar og skyld i ledelse. Spørgsmål om, hvad der er rigtigt, og hvad der er forkert at gøre og handle på eller ikke handle på i ledelse. Det kan være spørgsmål om skolen; dårlige lærere, som ikke bliver afskediget; alkoholiserede medarbejdere, som er nogle stakler; overordnede ledere, som træffer beslutninger på kanten af loven; politifolk, der ikke overholder de interne regler; ældrehjem, hvor de ansatte var meget hårdhændede over for de demente ældre. Jeg underviste en gang en leder, der fortalte om en beboer, der gik ud på en valgaften, og aldrig kom hjem igen. Beboeren blev aldrig fundet igen. Hvordan skal man som leder tænke om sig selv og sit ansvar i en sådan case?

Efter at have undervist 6 år i mit valgfag på MPG: "Eksistens og ledelse" besluttede jeg i 2012 at lave en interviewundersøgelse om, hvordan ledere opfattede ansvar og skyld i ledelse. Jeg var nysgerrig på hvilken måde "skyld" var noget, de forbandt med sig selv eller med noget andet. Til min overraskelse var det ikke noget, lederne umiddelbart var interesserede i at tale om. Skyld var tabuiseret. Det førte frem til følgende erkendelser: 
1. Skyld er den negative udgave af ansvar.

2. Ansvar er den positive udgave af skyld.

Samtidigt fortalte lederne mig historier fra deres arbejdsliv, som førte til tre kategorier af relationer mellem ansvar og skyld:

1. Lederen kan blive anklaget for at være skyldig, hvis han/hun ikke tager ansvar i tide.

2. Lederen kan rent faktisk tage ansvar, men stadigvæk blive anklaget for at være skyldig, hvis omgivelserne er uenige i beslutningen.

3. Lederen kan blive syndebuk for omstændigheder, han/hun overhovedet ikke havde indflydelse eller ansvar for.

Disse tre kategorier er indbyrdes forskellige, men ikke desto mindre viste ledernes historier, at ansvar og skyld i dagligdagssprog kommer til at hænge sammen. Dette førte til min bog Blod, sved og tårer: Om ansvar og skyld i ledelse (Sløk, 2014), hvor jeg beskrev de tre kategorier, og bogen blev til en del af min undervisning i de efterfølgende år.

De tre kategorier er blevet anvendt til efterfølgende analyser af de opgaver, som lederne skriver som en del af deres eksamen. I denne opgave skal lederen beskrive en case fra egen organisation og anvende teorierne fra "Eksistens og ledelse" på sin case. En gennemgang af 50 opgaver fra henholdsvis 2014 og 2017 viste, at når lederne skal fortælle deres historie og altså skaber et narrativ om deres organisation, er de begivenheder, der finder sted i narrativet, ikke begivenheder, der fører frem til den konklusion, at lederen er skyldig. Lederen er ikke skyldig i nogle af disse narrativer. I stedet fremtræder disse narrativer som situationer, hvor forskellige omstændigheder "gør" noget ved lederen, og hvor det som lederen ønskede, forsvinder ud af hænderne på lederen. Aktøren for begivenheden er "det uventede"; det som ingen - og slet ikke lederen - har ønsket sig. Narrativerne i opgaverne fra 2014 blev analyseret alene ud fra de ovenstående kategorier. I min analyse af narrativerne fra 2017 tilføjede jeg endnu en vinkel på de tre kategorier, nemlig Kenneth Burkes teori om dramatism, som indeholder følgende elementer: Act: What was done. Scene: Where it was done, Agent: Who did it, Agency: How the speaker did it - methods and technologies message strategies, storytelling, apologies for example, Purpose: Why it happened. (Burke, 1945). De fem elementer udgør dramaet i fortællingen. Interessant var det at iagttage, at en altovervejende del af lederne placerede sig selv i rollen som den Agent, der gik ind og ordnede problemerne, og at Purpose var at handle etisk rigtigt. Det er naturligvis positivt, at ledere ordner problemerne i deres egne fortællinger om deres ledelsespraksis, og at de gør det på en etisk måde, når de selv skal beskrive det. Det er samtidigt bemærkelsesværdigt, at ingen af lederne beskriver sig selv som en, der ikke kunne finde ud af problemerne, eller måske ligefrem selv var årsag til de problemer, der opstod i fortællingen. Da lederne beskriver deres egen ledelsespraksis, har denne positive selvfremstilling flere mulige fortolkninger: 1) De ledere, der tager faget "Eksistens og ledelse" er etisk korrekte og gør ikke noget forkert, 2) De ledere, der tager faget, kan ikke se, hvordan de eventuelt nogle gange selv kunne være en del af det problem, de beskriver, eller 3) Det er ganske enkelt meget vanskeligt for 
en leder at skrive, hvis han/hun mener, at han/hun har gjort noget forkert. Det er en selvfortælling, som måske nærmest er modstrid med ledelse, og vores forventninger til ledelse? "Skyld" er altså ikke lige noget, der er håndterbart eller skrivbart for lederne i deres ledelsesrefleksion. Ansvar er. Det kan lederne sagtens skrive om i forhold til deres ledelsespraksis. Men ikke om egen skyld.

Disse hidtidige undersøgelser, bl.a. på baggrund af de studerendes synopsebesvarelser, har gjort mig nysgerrig på (mindst) to spørgsmål: 1) Hvorfor skriver ingen af lederne i deres beskrivelse af deres cases i deres synopser: "Det, der skete, var helt utvetydigt min skyld"? og 2) gør det nogen forskel om man som leder har haft mit fag "Eksistens og ledelse" i forhold til éns opfattelse af ansvar og skyld? I 2017 besluttede jeg derfor at lave en undersøgelse af, hvad studerende, altså voksne ledere på vores MPG-uddannelse, bruger kategorierne ansvar og skyld til i deres ledelsespraksis.

\section{Undervisning i ansvar og skyld i ledelse}

Jeg startede i efteråret 2017, og i oktober 2018 var en spørgeskemaundersøgelse, der var baseret på en vignet, færdig. Spørgeskemaet var designet til at undersøge, hvorvidt ledere, der haft mit fag "Eksistens og ledelse" opfatter ansvar og skyld anderledes end ledere, der ikke har haft faget.

Vignetten tog udgangspunkt i en case med et dilemma, som de adspurgte (i alt 142) ledere fik muligheden for at svare på. Jeg konstruerede to grupper af respondenter. Den ene gruppe havde haft faget "Eksistens og ledelse". Den anden gruppe havde ikke haft faget. Jeg kalder i det følgende den gruppe, der har haft faget, for MEDgruppen. Og dem, der ikke har haft faget, for UDEN-gruppen. Formålet med dette var at undersøge om ledere, der har haft valgfaget, svarer anderledes end studerende, der ikke har haft valgfaget. 26 personer af 71 , i alt $36 \%$ af respondenterne, der havde haft faget, svarede på undersøgelsen. 21 personer, dvs. $29 \%$ af respondenterne, der ikke havde haft faget, svarede på undersøgelsen. Det vil sige, at ca. 1/3 ønskede at deltage i undersøgelsen. Som med alle undersøgelser, især kvantitative, ved vi ikke, hvorfor undersøgelsen bliver fravalgt.

\section{Artiklens opbygning}

Jeg vil i det følgende kort beskrive vignet-metoden og derefter beskrive de to cases, som lederne skulle svare på. Derefter vil jeg forklare baggrunden for dem, altså, hvorfor jeg valgte den vinkel. Det vil jeg gøre ved at forklare 1) min tidligere forskning, og derefter 2) vil jeg analysere ledernes svar på nedenstående to cases, for at prøve at kaste lys over, hvilke nye spørgsmål, deres svar giver.

\section{Metode}

Vignet-metoden (Monrad \& Ejrnæs, 2018) består i opbygning af en case, som respondenterne skal tage stilling til. Det er vigtigt at casen er genkendelig. Jeg brugte ni måneder på at udvikle casen. Dette skete ved at teste casen på 1) ledere, der havde 
haft mit valgfag, 2) ledere, der ikke havde haft valgfaget, 3) almindelige medarbejdere og 4) studerende fra mit bachelorfag, dvs. 60 studerende blev spurgt. Den sidste gruppe kendte begrebsapparatet, og skulle dermed have forudsætning for at forstå historien.

Når man bruger vignet-metoden, er det vigtigt, at casen er repræsentativ, dvs. forståelig, så respondenterne helt umiddelbart ved, hvad det er, man spørger om. Af denne grund valgte jeg alene at spørge ledere (MPG-studerende) fra 1) handicapområdet, og 2) socialområdet. Det er også vigtigt, at casen ikke er alt for "særlig", så den kommer til at ligne en undtagelsessituation.

Omvendt skal den også have kant nok til, at der er et problem til stede og derfor et dilemma omkring, hvordan man skal forstå problemet. Vignetmetoden beskriver to tilgange: Vertikal og horisontal. Horisontale vignetter ændrer lidt på historien i løbet af interviewet eller undersøgelsen, og folks besvarelser bliver analyseret i forhold til, om deres forklaringer ændrer sig, og hvad baggrunden kan være for dette. Vertikale vignetter ændrer derimod ikke på historien. De lader folk diskutere den samme historie for at se på, hvordan en gruppe af folk vurderer den samme historie. De to metoder har derfor også forskellige validitetskrav. Der er mest tradition for horisontale vignetter i en amerikansk, positivistisk tradition og mest tradition for vertikale vignetter i en nordisk tradition, hvor man har en eksplorativ tilgang til folks besvarelser, snarere end at måle afhængige variabler op ad uafhængige variabler, som er interessen i den horisontale metode (Monrad \& Ejrnæs, 2018). Jeg valgte den vertikale, fordi jeg var interesseret i, hvordan to grupper af folk ville forstå den samme historie. For det første egnede det valgte værktøj, nemlig et online-værktøj, sig ikke til flere cases omkring samme, som skulle ændre sig en lille smule af gangen. Det var simpelthen ikke muligt. For det andet var jeg interesseret i en eksplorativ tilgang til folks besvarelser, der gav deltagerne mulighed for at svare på åbne spørgsmål i forhold til emnerne ansvar, fejl og skyld (Gourlay et al., 2014). Denne mulighed for åbne spørgsmål gav deltagerne mulighed for at komme med deres egne erfaringer, hvilket også ændrer validitetskravet i de vertikale vignetter. I lighed med Gourley et al. (2014) blev jeg undervejs i afprøvningen af historien opmærksom på, at graden af grelhed skulle øges. Fra i første omgang blot at beskrive én situation, hvor noget gik galt, besluttede jeg mig for at opskalere konfliktniveauet i casen. Jeg indlagde derfor, 1) at ledelsen havde gjort noget, men ikke fulgt op på om der var blevet handlet efterfølgende, og 2) at der var undskyldende faktorer som forklarede de ansattes manglende handling.

Som bekendt kan forskellige metoder producere forskellige former for indsigt. Med vignetundersøgelsen fra 2018 ville jeg se på forskelle mellem de to grupper: Dem, der ikke havde haft faget (UDEN-gruppen), og dem, der havde haft faget (MED-gruppen). Man må imidlertid fastholde et metodisk forbehold i forhold til resultaterne. Man kan ikke på baggrund af denne lille spørgeskemaundersøgelse sige noget endeligt om, hvilken effekt undervisning i temaer som ansvar og skyld har, og heller ikke noget endeligt om, hvorvidt skyld generelt er et tabuiseret begreb i organisationer. Vi mangler stadig mere forskning - i større skala - på dette område. Vi mangler også semantiske næranalyser af, hvordan begreber som ansvar, fejl og skyld anvendes i forskellige situationer, og hvilke forskelle det producerer at anvende de forskellige begreber. Undersøgelsen her rejser således fortrinsvis spørgsmål, som vi får nogle indikative svar på. 


\section{- Udsendelse af link og svarmuligheder}

Linket til undersøgelsen blev sendt ud via uddannelsens sekretariat til de to grupper af studerende. Sekretariatet havde adgang til adresser på tidligere studerende. Både tidligere studerende på faget, og tidligere studerende, der ikke har haft faget.

Den gruppe, der havde haft faget, MED-gruppen, fik ét link. Den gruppe, der ikke havde haft faget, fik et andet link. Besvarelsen var anonym, og det kan ikke spores, hvem der har svaret hvad, hvilket heller ikke er relevant. Relevant er det derimod at sammenligne de to gruppers besvarelser i forhold til hinanden for at se, om der fremkom en forskel. Det fremgik ikke af udsendelsen, at min interesse var, om de to grupper ville svare forskelligt, da jeg ikke ønskede at instruere tidligere studerende fra "Eksistens og ledelse" til at skulle svare noget bestemt. Tværtimod var det interessant, hvad de ville svare, når de bare skulle svare som ledere. På den anden side skulle deltagerne afkrydse, om de havde haft faget "Eksistens og ledelse" for at sikre, at der var forskel på de to grupper. En fejl fra sekretariatets side i udsendelsen viste rent faktisk, at i MED-gruppen var der en, der svarede, at han/hun ikke vidste, om han/hun havde haft faget. Men han/hun var angivet i MPGs registreringssystem som en, der havde haft faget. Og i UDEN-gruppen var der én, der svarede, at han/hun havde haft faget. Disse to fejl blev først opdaget, da besvarelserne var kommet ind. De to links til vignetspørgeskemaet blev udsendt via onlineværktøjet Qualtrics, som CBS har licens til.

\section{- Beskrivelse af de to etiske cases}

Den første af to cases, som de 142 respondenter blev sat til at svare på i vignetspørgeskemaet, var følgende:

\section{Case 1:}

Q10 - Du skal vurdere følgende situation: Emil er vikar på et bosted. Bostedet er præget af mange vikarer. En dag glemmer Emil en handicappet beboer $\mathrm{i}$ rullestol på toilet. Alarmen på toilettet virker ikke. Beboeren ender med at sidde på toilettet i fem timer før nogen kommer og hjælper ham. Hvordan vil du vurdere denne situation i forhold til Emil?

Svarmulighederne var, at lederne skulle vurdere, om Emil 1) havde begået en fejl, 2) var skyldig i det skete, eller 3) var ansvarlig for det skete. Jeg var interesseret i, hvor inklineret respondenterne var i forhold til at bruge begreberne 1) fejl, 2) ansvar, eller 3) skyld i deres vurdering af casen. Grunden til at det er interessant er, at min tidligere forskning havde vist, at ledere generelt ikke er særligt interesserede i åbent at sige, at skyld er et begreb, der også bliver brugt i deres organisationer.

I stedet er ledere på den ene side politisk korrekte i ikke at bruge ordet skyld. På den anden side kunne selvsamme ledere fortælle mig tonsvis af historier om skyld, hvor de selv havde været dybt involveret, og enten var blevet anklaget for at være skyldige i ting, der gik galt, eller selv kunne anklage andre for at være skyldige i ting, der gik galt.

Der var altså en modstrid imellem, hvordan det så ud på overfladen ("her taler vi aldrig 
om skyld"), og så de dramaer, der foregik i kulissen ("hvem er skyld i x-forandring, eller $y$-fejl, eller at $z$ ikke bliver stoppet" osv.) Men man lod som om, man ikke havde disse vrede følelser og erfaringer omkring skyld.

Efter denne case skulle der svares på en case, hvor en anden medarbejder, Ulla, glemmer en beboer på et badeværelse en hel nat. Situationen er altså en tand værre end den foregående.

Case 2:

Q14 - Du skal vurdere følgende situation: Vi er på samme bosted som før. Bostedet : er præget af mange vikarer. Ugen efter sker det samme igen. En ny vikar, Ulla, glemmer en handicappet beboer, Susanne, på badeværelset. Alarmen på bad og toiletter virker stadig ikke. Det ender med, at beboeren, Susanne, sidder på badeværelset hele natten og indtil næste morgen, før rengøringen kommer og hjælper hende. Hvordan vil du vurdere denne situation i forhold til vikaren Ulla?

Her var begrebsmulighederne fuldstændigt de samme som i ovenstående. Ville de vurdere Ulla som 1) ansvarlig, 2) skyldig, eller at hun havde begået en fejl? Altså, hvilke ord ville de bruge for at betegne det, der var sket? Min interesse var, hvordan lederne ville betegne denne situation. Og ville der være forskel på de to respondent-grupper i forhold til den gruppe, der havde haft mit valgfag? Og den gruppe, der ikke havde haft mit valgfag? Begreberne er naturligvis åbne for fortolkning. "Skyld" kan fx defineres både juridisk, teologisk, socialt og moralsk. Jeg ville imidlertid ikke på forhånd præge, hvordan respondenterne skulle tolke begreberne, men have frem hvordan de ville vælge mellem at anvende "ansvar", "fejl" og "skyld". Lederne fik således i undersøgelsen flere gange mulighed for at vælge imellem de tre ord for at se, hvilket ord de foretrak at bruge om vignetternes historier.

\section{Analyse af resultater}

Det første resultat fremkom på baggrund af mere generelle spørgsmål, som ikke var direkte relateret til vignetterne.

\section{Første resultat: Der er forskel på, hvordan man opfatter ansvar og skyld som begreb}

Dette resultat baserer sig på følgende to spørgsmål spørgeskemaundersøgelsen:

1. Spørgsmålet "Ansvar og skyld er to sider af samme sag".

2. Spørgsmålet om, hvad andre mener om ledelsens ansvar.

I forhold til disse spørgsmål skulle respondenterne svare på, hvor enige de var. Man kunne svare fra på en skal fra 1) meget uenig, 2) uenig, 3) neutral, 4) enig til 5) meget enig på alle spørgsmål, undtagen valg af sætning til beskrivelse af situationen. Til det første punkt har MED-gruppen en bredere besvarelse, med mindre enighed. Ansvar og 
skyld hænger muligvis/muligvis ikke sammen. $53 \%$ er uenige i, at ansvar og skyld er to sider af samme sag. Mens $39 \%$ mener, at de to ting hænger sammen.

UDEN-gruppen mener helt overvejende, at disse to begreber intet har med hinanden at gøre. Således svarer 80 \% af UDEN-gruppen, at de var meget uenige eller uenige i sætningen: "Ansvar og skyld er to sider af samme sag". Det er kun 9 \%, der er meget enige eller enige i, at de to ting hænger sammen.

Det kunne altså se ud som om, at man ser sammenhængen mellem ansvar og skyld forskelligt, afhængigt af om man har haft faget eller ej.

I forhold til det andet spørgsmål ("Ledelsen får skylden, selvom de har taget ansvar") varierer det imellem de to grupper, hvordan de mener andre vil forstå sagen. Det er altså et spørgsmål, der går på at træne det, at ledelsen jo bliver iagttaget og ikke selv kan bestemme, hvad andre i omverdenen ser.

I MED-gruppen kan et flertal af lederne godt se, at ledelsen får skylden, selvom de har taget ansvar. Det mener næsten 54 \%. $27 \%$ er uenige. Dette tal fordeler sig lidt overraskende for UDEN-gruppen. Her er det næsten $43 \%$, der er meget uenige eller uenige. Samtidigt er $43 \%$ af UDEN-gruppen meget enige eller enige! Dvs. antallet af a) Meget Enig/Enig, og b) Meget Uenig/Enig fordeler sig præcist mellem de to ender af spektret.

Der er ganske enkelt ikke noget entydigt svar for dem, der ikke har haft faget.

Spørgsmålet er, som med de andre grupper, om man skal forstå det således, at faget giver lederne (de studerende) et værktøj til at forstå en case som denne på en anden måde? At man som ledelse kan få skyld, selvom man har handlet? Eller om lederne blot bedre forstår kategorien fordi de har haft undervisning i det? Det kan man ikke umiddelbart sige noget om ud fra disse besvarelser. Vi kan blot konstatere en forskel.

MED-gruppen:

\begin{tabular}{|l|ll|l|}
\hline Ledelsen & Meget enig & $23.08 \%$ & Meget enig eller enig: \\
får skylden, & Enig & $30.77 \%$ & $53.85 \%$ (oprundet 54\%) \\
selvom de har & Neutral & $19.23 \%$ & \\
taget ansvar. & Uenig & $19.23 \%$ & Meget uenig eller uenig: \\
& Meget uenig & $7.69 \%$ & $26.92 \%$ \\
& & \\
\end{tabular}

UDEN-gruppen:

\begin{tabular}{|l|ll|l|}
\hline Ledelsen & Meget enig & $4.76 \%$ & Meget enig eller enig: \\
får skylden, & Enig & $38.10 \%$ & 42.86\% (oprundet 43\%) \\
selvom de har & Neutral & $14.29 \%$ & \\
taget ansvar. & Uenig & $38.10 \%$ & Meget uenig eller uenig: \\
& Meget uenig & $4.76 \%$ & 42.86\% (oprundet 43\%) \\
& & \\
\end{tabular}




\section{- Andet resultat: Der er forskelle i, om man tør bruge begrebet "skyld" om medarbejdere.}

Når vi bevæger os til spørgsmålene vedrørende vignetterne, ser vi, at MED-gruppen har mindre imod at vælge ordet "skyld" om Emil og Ullas glemsomhed end UDENgruppen. UDEN-gruppen undgår helst ordet skyld. 49 \% fra MED-gruppen mener, at man godt kan bruge ordet "Emil er skyld i, at beboeren sidder der så længe". Det mener kun $23 \%$ procent i UDEN-gruppen, at man kan sige. Det kunne se ud som om, at ledere, der har haft faget, er mindre bange for at bruge ordet "skyld".

Samme forskel gør sig gældende i det lidt grovere tilfælde, hvor Ulla, den anden medarbejder, glemmer en beboer, der efterfølgende sidder på badeværelset hele natten. I MED-gruppen mener $50 \%$, at man godt kan tale om, at det er hendes skyld, mens det stadigvæk kun er 24 \% i UDEN-gruppen, der mener, at man kan tale om hendes skyld.

Hvis man har haft faget, ser det altså ud som om, at man er mere tilbøjelig til at tale eksplicit om "skyld" end hvis man ikke har haft det. Om det er positivt eller negativt, afhænger af, om man opfatter italesættelse af skyld som en del af organisationers hverdag og liv, eller om man mener - som nogle gør - at det skal man slet ikke tale om. Altså at det foretrækkes, at skyld er tabuiseret eller simpelthen helt væk fra organisationens hverdag.

\begin{tabular}{|l|ll|l|}
\hline MED-gruppe: & Meget enig & $19.23 \%$ & Meget enig eller enig: \\
Ulla er skyld i, at & Enig & $30.77 \%$ & $50 \%$ \\
beboeren sidder der så & Neutral & $7.69 \%$ & \\
længe (hele natten). & Uenig & $38.46 \%$ & Meget uenig eller uenig: \\
& Meget uenig & $3.85 \%$ & $42 \%$ \\
& & & \\
\hline
\end{tabular}

\begin{tabular}{|l|ll|l|}
\hline UDEN-gruppe: & Meget enig & $9.52 \%$ & Meget enig eller enig: \\
Ulla er skyld i, at & Enig & $14.29 \%$ & $24 \%$ \\
beboeren sidder der så & Neutral & $14.29 \%$ & \\
længe (hele natten). & Uenig & $57.14 \%$ & Meget uenig eller uenig: \\
& Meget uenig & $4.76 \%$ & $62 \%$ \\
\hline
\end{tabular}

Derimod er både MED- og UDEN-gruppen enige om, at "Emil har begået en fejl" (henh. 84 \% og 86 \%). Dette kunne pege på, at ordet "fejl" er nemmere at bruge for begge parter end ordet "skyld". 
- Tredje resultat: Der er forskel på, hvordan man vurderer ledelsens rolle

I spørgsmål 17, 18 og 19 skulle respondenterne vurdere følgende tre sætninger:

1) Ledelsen har ansvar for, at den slags ting kan ske to gange.

2) Ledelsen har fejlet, når den slags ting kan ske to gange.

3) Ledelsen er skyld i, at den slags ting sker to gange.

Respondenterne skulle vælge mellem "Meget uenig", "Uenig", "Neutral", "Enig" og "Meget enig". Her svarer MED-gruppen med ca. 42 \% i kategorierne "Enig" og "Meget enig", OG med 46 \% i kategorierne "Meget uenig" og "Uenig".

Der er meget større variation i MED-gruppen end i UDEN-gruppen på besvarelsen om, hvorvidt det er ledelsens skyld, at den slags kan ske to gange, eller om det ikke er.

\begin{tabular}{|l|ll|l|}
\hline MED-gruppe & Meget enig & $11.54 \%$ & Meget enig eller enig: \\
Ledelsen er skyld i, at den & Enig & $30.77 \%$ & $42 \%$ \\
slags ting sker to gange. & Neutral & $11.54 \%$ & \\
& Uenig & $38.46 \%$ & Meget uenig eller uenig: \\
& Meget uenig & $7.69 \%$ & $46 \%$ \\
& & & \\
\hline
\end{tabular}

\begin{tabular}{|l|ll|l|}
\hline UDEN-gruppe: & Meget enig & $9.52 \%$ & Meget enig eller enig: \\
Ledelsen er skyld i, at den & Enig & $4.76 \%$ & $14 \%$ \\
slags ting sker to gange. & Neutral & $19.05 \%$ & \\
& Uenig & $61.90 \%$ & Meget uenig eller uenig: \\
& Meget uenig & $4.76 \%$ & $66 \%$ \\
\hline
\end{tabular}

UDEN-gruppen mener igen ikke, at man skal bruge ordet "skyld". I hvert fald er flertallet uenige i et sådant sprogbrug, mens MED-gruppen har større variation i, om ordet "skyld" på kvaliteten af ledelsens opgaveløsning kan bruges her.

Derimod er begge grupper enige om, at det er ledelsens ansvar, og at ledelsen har fejlet.

Til gengæld vil ingen af de to grupper foretrække sætningen: "Ledelsen har skylden". På spørgsmålet om, hvilket ord de helst vil bruge om ledelsens rolle, svarer 0 \% fra MED-gruppen, at de foretrækker sætningen: "Ledelsen har skylden". 96 \% foretrækker sætningen: "Ledelsen har ansvaret". Det er samme i UDEN-gruppen: 95 \% svarer, at de foretrækker sætningen "Ledelsen har ansvaret". $0 \%$ svarer, at de foretrækker "Ledelsen har skylden". 


\begin{tabular}{|l|ll|l|}
\hline MED-gruppe: & Ledelsen har fejlet. & $3.85 \%$ & Ledelsen har ansvaret: \\
Hvilken sætning vil & Ledelsen har skylden. & $0.00 \%$ & $96,15 \%$ \\
du helst bruge om & Ledelsen har ansvaret. & $96.15 \%$ & \\
det, der er sket? & Ved ikke & $0.00 \%$ & Ledelsen har skylden \\
& & $0 \%$ \\
\hline
\end{tabular}

\begin{tabular}{|l|ll|l|}
\hline UDEN-gruppe: & Ledelsen har fejlet. & $4.76 \%$ & Ledelsen har ansvaret: \\
Hvilken sætning vil & Ledelsen har skylden. & $0.00 \%$ & $96,15 \%$ \\
du helst bruge om & Ledelsen har ansvaret. & $95.24 \%$ & Ledelsen har skylden \\
det, der er sket? & Ved ikke & $0.00 \%$ & $0 \%$ \\
\hline
\end{tabular}

Dette er bemærkelsesværdigt, når man sammenligner med resultatet ovenfor, hvor $42 \%$ i MED-gruppen er meget enige eller enige i, at ledelsen er skyld i, at det kan ske to gange. Hvorfor vælger så ingen i MED-gruppen sætningen "Ledelsen har skylden"?

Man kan forstå det således, at "skyld" er tabuiseret. Mens fejl og ansvar for ting, der går galt, kan gå an. Dette bekræftes også af spørgsmål 9 om, hvordan de forstår ordene 1) ansvar, 2) fejl, og 3) skyld. Respondenterne bliver spurgt, om, hvorvidt de tre ord er positive, og skal vurdere dette fra en skala fra Meget uenig, Enig, Neutral, Uenig og Meget uenig. $83 \%$ af UDEN-gruppen mener ikke at skyld er positivt. Og resten er neutrale. Ingen siger "Enig". I MED-gruppen svarer $85 \%$, at skyld er et negativt ord, mens $89 \%$ af MED-gruppen mener, at ansvar er et positivt ord. $40 \%$ i MEDgruppen svarer "Uenig eller Meget uenig" til, at fejl er positivt. $33 \%$ svarer "Neutral" til ordets betydning. UDEN-gruppen mener klart, at ledelsen har et ansvar, og skulle have handlet i tide. Samtidigt mener de ikke, at ordet "skyld" er passende, hverken på ledelsens manglende handlen eller på medarbejdernes (Emil og Ullas) manglende handlen.

Dette peger igen hen på teoretisk usikkerhed omkring, hvad "ledelsesansvar" så er for noget, herunder hvad det personlige lederskab går ud på, når det drejer sig om disse svære emner. I hvert fald kan vi se, at ledere opfatter ansvar som positivt, fordi de kan handle, og skyld som uattraktivt, fordi det er noget, man ikke kan gøre noget ved. Nogle siger endda, at skyld er fortidigt, og derfor ikke interessant. Vi skal åbenbart videre. Vi skal altid se fremad.

\section{Diskussion}

Det svære i alle disse cases er både det etiske, men også det intellektuelle. Eller det epistemologiske: Hvordan kan vi overhovedet tænke om lederens ansvar i forhold til ting, der går galt? Er det lederen, som menneske, den er gal med, hvis der foregår mindre heldige eller ligefrem vanvittige ting i ens organisation? Eller er det blot og alene rollen eller kulturen, som vi kan bebrejde, og heri den figur, som lederen bliver i organisationen? Det ville støtte en Max Webersk tilgang, som beskrevet ovenfor, og også Chester Barnard. Det personlige lederskab som teori er stadigvæk ikke 
færdigudviklet på dette punkt. Eller betaler vi netop for, at lederen ikke bare følger med strømmen (kulturen), men sætter sig igennem og gør det rigtige? Det ville støtte Bernard Bass' forståelse af lederen som karismatisk og altafgørende for organisationens udførende funktioner.

Men hvad så hvis lederen ikke kan det? Er han/hun så et ringere menneske end andre? Hvordan kan de eksisterende teorier forklare det forhold, at ledere generelt ikke synes, at "skyld" har noget med dem at gøre, hvis tingene går galt? Vi har en strømning inden for organisationslitteraturen, som besvarer dette emne, nemlig "Hjælp, min chef er psykopat"-litteraturen (Udsen, 2013). En psykopat er primært karakteriseret ved ikke at føle skyld (Hare, 1999). Men er alt forklaret ved blot at pege på psykopatibegrebet? Jeg mener, at ledelseslitteraturen har en svaghed her, og at det i højere grad er fag som moral, etik, teologi og filosofi, der kan forholde sig til bagsiden af ledelsen: skylden, skammen, sorgen, de onde og det onde. Mens der uden tvivl findes psykopater, som det gælder om at holde sig fra og løbe skrigende bort fra, så er der masser af andre sociale situationer i organisationer, som ikke kan besvares alene med et sygdomsbegreb. Man er ikke psykopat, selvom man bliver nødt til som leder at gøre noget træls. Dette spørgsmål om, hvordan det at gøre "det nødvendige onde" trænger til en ny kategori i ledelsesteori, hvilket jeg kun kan berøre indirekte i denne artikel.

Jeg vil forsøge at forholde mig til det spørgsmål, jeg stillede indledende, nemlig, hvorfor begrebet "skyld" har så ringe genklang blandt ledere, mens alle andre, herunder journalister og forskere i psykopati, tager det for givet, at alle mennesker har evnen til at føle skyld, og derfor også burde føle det, når de er ledere for organisationer, der gør forkerte ting.

Vi kan på den ene side ikke sige, at ledere skal mene, at de er skyld i ting, der går galt i deres organisation. Vi kan på den anden side konstatere, at omverdenens forventninger peger i den retning: Ledere FÅR skylden, når ting går galt i deres organisation.

Projektet er nu at finde ud af, hvordan denne skyldshåndtering i ledelse så finder sted bedst muligt. Ikke bare bedst muligt for lederen, som selvfølgelig altid gerne vil se godt ud. Det er menneskeligt. Men vi må blive klogere på, hvilken skyldshåndtering der er bedst i forhold til sagen, nemlig det, der er gået galt, og dem, det er gået ud over (Hearit, 2006).

Dette spørgsmål bringer mig til det sidste spørgsmål vedr. det personlige lederskab. Spørgsmålet om "skyld" sætter netop spørgsmålstegn ved, hvad "det personlige" i lederskabet egentligt er. Dette vil jeg samle op på i følgende konklusion. 


\section{Konklusion}

Resultatet på vignetundersøgelsen 2018 var, at der var stor forskel på svarene fra de to grupper af respondenter, der henholdsvis havde haft og ikke havde haft faget "Eksistens og ledelse". Der var tre hovedresultater:

Resultat 1: Der er forskel på, hvordan man opfatter ansvar og skyld som begreb.

Resultat 2: Der er forskel på, om man tør bruge begrebet "skyld" om medarbejdere.

Resultat 3: Der er forskel på, hvordan man vurderer ledelsens rolle.

Det første resultat indeholder at den gruppe, der havde haft Eksistens og ledelse (MED-gruppen), i højere grad mente, at ansvar og skyld hænger sammen. Det er ikke overraskende, eftersom det er det, faget handler om.

Ledere, der har haft faget, har lettere ved at bruge ordet "skyld" om de to medarbejderes fejl. Således mente 50 \% i MED-gruppen, at Ulla er skyld i, at beboeren sidder der hele natten. 49 \% mente også her, at Emil var skyld i, at beboeren sad fem timer på toilettet. Der er således en anden tendens til at bruge ordet "skyld", hvis man har haft faget Eksistens og ledelse. Om dette er positivt eller negativt, er ikke lige til at udlede af denne undersøgelse.

Mere overraskende er det, at et flertal af dem, der ikke har haft faget, ikke ser nogen sammenhæng mellem ansvar og skyld. De to ting er helt forskellige for den leder, som er gået uden om mit valgfag. Det bekræfter helt umiddelbart det, som allerede min første undersøgelse fra 2012 viste, nemlig at ledere ikke umiddelbart ser nogen sammenhæng mellem ansvar og skyld, selvom de ved nærmere eftertanke gør sig mange erfaringer med dette, hvis man spørger ind til de begivenheder i deres lederskab som har gjort mest indtryk på dem. Måske er dette bagsiden af den måde, hvorpå man forstår det personlige lederskab, som Bernard Bass har stået som eksponent for? Det personlige lederskab og personbegrebet i det er ikke udfoldet nok teoretisk set. At der er problemer med, hvad det personlige ansvar er i det personlige lederskab, er måske også en af de pointer man kan udlede af kritikken af uddannelserne på de vestlige business schools. Bl.a. på Harvard Busines School har man reflekteret over, hvordan business schools kan være med til at udvikle en manglende stillingtagen fra ledere og andre organisationsmedlemmer i forhold til konsekvenserne af deres beslutninger (se fx Podolny, 2009; Jaiwal, 2015). Dette kunne siges at føre til de finansielle kriser, vi har set de sidste 10 år i forskellige former: Boligmarkedssammenbruddet i 2008, men også Panama-Papers, Swiss Leaks, og CumEx Files, hvor finansfolk og advokater har arbejdet sammen om at snyde med hvidvask, skatteunddragelse og tyveri fra vestlige statskasser, er eksempler på skruppelløs og distancerede ledelsesbeslutninger, som truer de vestlige demokratier og økonomi. Også i det offentlige er der skandaler, hvor lederens ansvar og skyld er uklart. Fx SKATs EFI-system-skandale, udbytteskatudbetaling til trods for advarsler, lukning af børnesager i Odense kommune til trods for brud på forvaltningsloven, børnesager som Tønder, Brønderslev og Slagelse, hvor omsorgssvigt er blevet ignoreret fra tilsynsmyndighedens side. Hvilken form for ansvar har ledere og politikere her? Der er altid travlt ved håndvasken, når ligene vælter frem fra skabene. 
Hvis man forsigtigt skal konkludere noget af disse 47 besvarelser, så giver faget måske lederne nogle værktøjer til at håndtere forventninger til ledelse i forhold til ansvar og skyld, idet de MED-gruppen i højere grad kan anvende ansvar og skyld på disse cases, fremfor at ignorere begrebernes relevans. De ledere, der har haft "Eksistens og ledelse" har en mere nuanceret brug af ordet "skyld" end dem, der ikke har haft det. Ledere, der ikke har haft faget, afviser helt "skyld" som relevant for ledelses-, og organisationsbeslutninger og begivenheder.

Der kan ses flere mulige konsekvenser af forskydelsen i lederskabet mellem ansvar og skyld. Hvis alle synes, at ansvar er positivt, men ingen vil tage skylden, må det betyde noget for, hvordan vi forstår ledelse. Ikke mindst det personlige lederskab. Nogle mener derfor også, at man skal opgive det personlige lederskab som begreb. Andre som fx Ledelseskommissionen peger på, at vi skal opgradere det personlige lederskab. Det er jeg enig i.

Der er en stor sandhed gemt i det faktum, at folk ikke bare følger lederen i kraft af positionen, men at der skal noget mere til: nemlig personen i lederskabet. Derfor mener jeg, at vi kommet til en tid, hvor det er nødvendigt at se nærmere på etikken i det personlige lederskab i forhold til det politiske, som er spørgsmålet om, hvordan vi vælger at leve sammen som samfund og som organisationer.

Vi skal diskutere meget mere, både teoretisk og praktisk, 1) hvordan lederen skal agere etisk i et politisk rum, og 2) de etiske og politiske konsekvenser af de beslutninger, som ledere og medarbejdere træffer i deres dagligdag i forhold til deres kerneopgave. Disse dimensioner er ikke endnu skrevet tydeligt frem i forhold til "leadershiplitteraturen". Denne litteratur fokuserer primært på "den fantastiske leder", og mindre på de vilkår, som lederen agerer i og agerer under. Valgfaget "Eksistens og ledelse" er et sådant læringsrum for etiske overvejelser i det flerdimensionelle personlige lederskab, og det ser ud til at være meget godt i tråd med den offentlige debat, der i højere grad er begyndt at efterlyse stillingtagen til nogle af disse tematikker.

\section{Ledelsesmæssige implikationer}

Langt de fleste ledere er ordentlige og rationelle mennesker. Når jeg møder ledere på MPG, udtrykker de ikke sjældent undren over, hvordan både medarbejdere, borgere, politikere og andre aktører omkring lederne indimellem er i deres følelsers vold. Medarbejdere er vrede, borgere er kede af det, politikere er rasende... Lederne forventer rationalitet men møder indimellem voldsomme følelser og protest. Især når noget går galt. Mine anbefalinger ud fra min forskning i relationen mellem ansvar og skyld peger på følgende konklusioner, som ledere ville vinde ved at reflektere over i forhold til deres organisation:

1. Når noget går galt, leder den forurettede part som regel efter årsagen. Hvis skaden er stor, vil følelserne også være tilsvarende store, og en del af disse følelser er følelser af vrede og sorg. Dette fremkalder som oftest ønsket om at finde den ansvarlige eller skyldige og få genoprettet retfærdigheden. Eller i det mindste blive anerkendt i sit tab. 
2. Ledere skal således være bevidste om, at der altid foregår et shame-and-blamespil, hvor ledere kan blive syndebukke for forhold, som de intet ansvar har for.

3. Af ovenstående grund bør ledere også øve sig på at finde "en grimasse, der kan passe", altså udvikle en persona eller et face som en måde at håndtere problemet på. Det betyder også, at ledere bør blive bedre til at undskylde på vegne af deres organisation, når de fejler. Det kan selvfølgelig også være på egne vegne, hvis det er lederen, der har gjort noget forkert eller begået en fejl.

4. Sidst men ikke mindst handler fejl og skyld om forsoning og tilgivelse. Ledere er ledere for mennesker, og mennesker er ikke altid perfekte. De begår fejl, også selvom de ikke vil. 


\section{Referencer}

Barnard, C. (1968). The functions of the executive. Cambridge: Harvard University Press.

Bass, B. (1985). Leadership beyond expectation. New York: Free Press.

Burke, K. (1945). A Grammar of Motives. Berkeley: University of California Press

Burke, K. (1970). The Rhetoric of Religion: Studies in Logology. Oakland: University of California Press.

du Gay, P. (2007). Hyldest til bureaukratiet: Weber, organisation, etik. København: Hans Reitzels Forlag.

Gourlay, A., Mshana, G., Birdthistle, I., Bulugu, G., Zaba, B., \& Urassa, M. (2014). Using vignettes in qualitative research to explore barriers and facilitating factors to the uptake of prevention of mother-to-child transmission services in rural Tanzania: a critical analysis. BMC Medical Research Methodology (14) 21.

Hare, R. (1999). Without Conscience: The Disturbing World of the Psychopaths Around US. New York: The Guilford Press.

Podolny, J. M. (2009). Are Business Schools to Blame? Harvard Business Review https://hbr.org/2009/03/are-business-schools-to-blame

Hearit, K. M. (2006). Crisis management by apology: Corporate response to allegations of wrongdoing. London: Routledge.

Jaiswal, A. (2015). What's wrong with business schools? University World News. http:// www.universityworldnews.com/article.php?story $=20150225090458334$, 27. februar

Monrad, M. \& Ejrnæs, M. (2012). Vignetmetoden. Sociologisk metode og redskab til faglig udvikling. København: Akademisk Forlag.

Sløk, C. (2014). Blod, sved og tårer: Om ansvar og skyld i ledelse. København: Djøf Forlag.

Udsen, S. (2013). Parasitter i habitter. København: Lindhardt \& Ringhof.

Weber, M. (1971). Parlament und Regierung in neugeordneten Deutschland.

I: Gesammelte Politische Schriften. (3. udgave, s. 306-443). Tübingen: J.C.B. Mohr. 